\title{
Lilin sebagai Konteks Materi Tabung pada LKPD Berbasis PMRI
}

\author{
Amatullah Mu'tashimah ${ }^{1 *}$, Agustiany Dumeva Putri ${ }^{2}$, \& Feli Ramury ${ }^{3}$ \\ ${ }^{1,2,3}$ UIN Raden Fatah Palembang, Palembang, Indonesia
}

\section{INFO ARTICLES}

Article History:

Received: 02-12-2020

Revised: 23-12-2020

Approved: 23-12-2020

Publish Online: 25-12-2020

\section{Key Words:}

Student Worksheet; Cylinder; Realistic Mathematics Education Approach;

\section{(i) (2)} under a Creative Commons AttributionShareAlike 4.0 International License.

\begin{abstract}
This research aims to produce a valid and practical Student Worksheet with Indonesian Realistic Mathematics Education approach on cylinder material. This research is a development research consisting of preliminary stage and prototyping stage using the Tessmer flow formative evaluation consisting of self-evaluation, expert review, one to one, small group, and field test. Data collection techniques used in this study were walkthrough, documentation, student response questionnaires, and interviews. The results of this research are: (1) this research has produced Student Worksheets based on Indonesian Realistic Mathematics Education approach which are valid based on comments and suggestions given by the validator and declared valid by the validator at the expert review stage. (2) this research has produced Student Worksheets based on Indonesian Realistic Mathematics Education approach which are practical based on the results of the calculation of student response questionnaires in the one to one, small group, and field test stages.
\end{abstract}

\begin{abstract}
Abstrak: Penelitian ini bertujuan untuk menghasilkan LKPD berbasis pendekatan PMRI pada materi tabung yang valid dan praktis. Penelitian ini merupakan penelitian pengembangan yang terdiri dari tahap preliminary dan tahap prototyping menggunakan formative evaluation alur Tessmer yang terdiri dari self evaluation, expert review, one to one, small group, dan field test. Teknik pengumpulan data yang digunakan dalam penelitian ini adalah walkthorugh, dokumentasi, angket respon peserta didik, dan wawancara. Hasil dari penelitian ini adalah: (1) penelitian ini telah menghasilkan LKPD berbasis pendekatan PMRI yang valid berdasarkan komentar dan saran yang diberikan validator dan dinyatakan valid oleh validator pada tahap expert review. (2) penelitian ini telah menghasilkan LKPD berbasis pendekatan PMRI yang praktis berdasarkan hasil perhitungan angket respon peserta didik pada tahap one to one, small group, dan field test.
\end{abstract}

Correspondence Address: Jln. Prof. K. H. Zainal Abidin Fikri No. 1, Palembang, 30126, Indonesia; e-mail: amutashimah@gmail.com

How to Cite (APA $6^{\text {th }}$ Style): Mu'tashimah, A., Putri, A. D., \& Ramury, F. (2020). Lilin Sebagai Konteks Materi Tabung pada LKPD Berbasis PMRI. JKPM (Jurnal Kajian Pendidikan Matematika), 6(1): 83-98

Copyright: 2020 Amatullah Mu’tashimah, Agustiany Dumeva Putri, Feli Ramury

Competing Interests Disclosures: The authors declare that they have no significant competing financial, professional or personal interests that might have influenced the performance or presentation of the work described in this manuscript. 


\section{PENDAHULUAN}

Matematika merupakan mata pelajaran yang diberikan di semua tingkat pendidikan mulai dari pendidikan dasar hingga pendidikan menengah. Menurut Septiyani \& Apriyanto (2019: 154) matematika merupakan ilmu yang mendasari perkembangan teknologi serta mempunyai peranan penting dalam mengembangkan daya pikir manusia. Azis (2019: 65), mengemukakan bahwa matematika merupakan ilmu yang selalu diidentikkan dengan segala sesuatu yang bersifat abstrak, perhitungan, penalaran, menghafal rumus, keaktifan berfikir, dan pemahaman-pemahaman teorema yang digunakan sebagai dasar mata pelajaran eksak lainnya. Menurut Haryonik \& Bhakti (2018: 42), dalam kegiatan pembelajaran matematika, guru diharapkan memperhatikan bahan ajar yang digunakan untuk mencapai tujuan pembelajaran.

Bahan ajar merupakan komponen penting dalam suatu proses pembelajaran karena bahan ajar dapat memudahkan peserta didik dalam memahami materi yang disampaikan oleh guru. Berdasarkan hasil wawancara dengan salah satu guru di SMP Negeri 40 Palembang, sekolah tersebut hanya menggunakan buku paket sebagai bahan ajar dalam proses pembelajaran. Berdasarkan hasil wawancara dengan peserta didik diperoleh informasi bahwa peserta didik mengalami kesulitan dalam mempelajari materi yang terdapat pada buku paket. Menurut peserta didik, langkah pengerjaan dalam buku paket kurang bisa dimengerti dan bahasa yang digunakan pada buku paket cukup sulit untuk dipahami sehingga peserta didik merasa sulit untuk memahami materi yang ada pada buku paket. Selain itu, proses pembelajaran matematika yang dilaksanakan masih berpusat pada guru (teacher centered). Hal ini sejalan dengan yang dikatakan Lado (2016: 1) bahwa pembelajaran matematika di kelas masih terpusat pada guru, dimana peserta didik hanya dilatih untuk melakukan perhitungan matematika dengan rumus yang tidak pernah diketahui dari mana asalnya. Menurut Andari \& Komsiatun (2018: 156), salah satu bahan ajar yang dapat digunakan untuk menunjang materi pembelajaran adalah Lembar Kerja Peserta Didik (LKPD).

LKPD merupakan lembaran-lembaran yang berisi tugas, baik berupa soal-soal maupun kegiatan yang harus dikerjakan oleh peserta didik sebagai sarana untuk mencapai suatu tujuan. Prastowo (2014: 439) mengatakan bahwa LKPD merupakan suatu bahan ajar cetak yang berupa lembar-lembar kertas berisi materi yang akan dipelajari, rangkuman, dan petunjuk pelaksanaan tugas pembelajaran yang harus dikerjakan oleh peserta didik, baik bersifat teoritis maupun praktis, yang mengacu kepada kompetensi dasar yang harus dicapai peserta didik.

Selain penggunaan bahan ajar, penggunaan pendekatan pembelajaran juga diperlukan oleh guru dalam melaksanakan pembelajaran matematika. Hal ini sejalan dengan yang disampaikan oleh Ali \& Rarini (2014: 231) bahwa penggunaan pendekatan pembelajaran diperlukan guru dalam pembelajaran agar peserta didik memahami konsep yang sedang dipelajarinya. Pendekatan pembelajaran yang dapat digunakan adalah pendekatan Pendidikan Matematika Realistik Indonesia (PMRI). Atika \& MZ (2016: 104), mengatakan bahwa PMRI merupakan pendekatan pembelajaran yang menggunakan masalah kontekstual sebagai titik awal pembelajaran untuk menunjukkan bahwa matematika sebenarnya sangat dekat dengan kehidupan sehari-hari peserta didik. Hal yang sama juga disampaikan Jannah \& Towafi (2020: 166) bahwa PMRI merupakan pembelajaran matematika yang mengaitkan konsep abstrak matematika dengan pengalaman sehari-hari dan kehidupan nyata. Lebih lanjut, penelitian Utarni \& Mulyatna (2020), mengambil kejadiankejadian yang menjadi pengalaman keseharian siswa sebagai pengantar dalam menjelaska/mengaitkan konsep matematika. Dapat disimpulkan bahwa pendekatan PMRI merupakan pendekatan pembelajaran matematika yang menggunakan konteks pada saat pembelajaran.

Penggunaan konteks dalam proses pembelajaran dapat memudahkan peserta didik dalam memahami materi yang sedang dipelajari. Hal ini sejalan dengan Wijaya (2012: 31) yang mengatakan bahwa penggunaan konteks dapat membuat konsep matematika menjadi lebih bermakna bagi peserta didik karena 
konteks dalam pembelajaran dapat menyajikan konsep matematika abstrak dalam bentuk representasi yang mudah dipahami oleh peserta didik. Penggunaan konteks merupakan salah satu karakteristik dari pendekatan PMRI. Menurut Wijaya (2012: 21) konteks yang digunakan dalam pembelajaran tidak harus berupa permasalahan dunia nyata namun bisa berupa penggunaan alat peraga, permainan, atau situasi lain selama hal tersebut bermakna dan dapat dibayangkan dalam pikiran peserta didik. Isrok'atun (2018: 73) mengatakan bahwa peran peserta didik dalam proses pembelajaran matematika dengan pendekatan PMRI dijadikan sebagai subjek belajar. Hal ini menuntut peserta didik untuk memberikan kontribusi dalam kegiatan belajar, yang meliputi ide, gagasan, maupun argumen tentang konsep matematika yang sedang dipelajarinya.

Salah satu materi matematika yang sering digunakan dalam kehidupan nyata dan terdapat banyak konsep adalah bangun ruang tabung. Namun, penguasaan konsep yang dimiliki peserta didik dalam menyelesaikan soal penerapan bangun ruang tabung belum sepenuhnya dikuasai peserta didik. Peserta didik hanya menghafal rumus luas dan volume tabung sehingga pemahaman konsep peserta didik terhadap materi bangun ruang tabung masih belum optimal. Khairani \& Febrinal (2016: 95-96) dalam penelitiannya menyatakan bahwa peserta didik hanya menghafal rumus luas dan volume dari bangun ruang bahkan diantaranya ada beberapa peserta didik yang keliru dengan rumus luas dan volume tabung. Hal yang sama juga terdapat dalam penelitian Nuraida (2017: 30) bahwa peserta didik terbiasa menghafal rumus dan sering tertukar antara rumus luas tabung dan volume tabung. Selain itu, Arifin, Yusmin, \& Hamdani (2017: 8) dalam penelitiannya menyatakan bahwa salah satu kesulitan belajar peserta didik pada materi bangun ruang sisi lengkung yaitu peserta didik tidak mampu mengingat rumus luas permukaan dan volume tabung. Hal ini disebabkan oleh metode yang digunakan guru pada saat mengajar cenderung menggunakan metode ceramah yaitu hanya menjelaskan materi, sedikit tanya jawab kemudian memberikan soal latihan.

Berkaitan dengan penelitian sebelumnya, ada beberapa penelitian yang telah mengembangkan LKPD berbasis pendekatan PMRI. Dari hasil penelitian yang dilakukan Heriyadi \& Prahmana (2020: 409), Lembar Kerja Peserta Didik (LKPD) dengan pendekatan PMRI pada materi kubus dan balok yang dihasilkan valid, praktis, dan memiliki efek potensial terhadap kemampuan literasi matematis peserta didik. Adapun perbedaan antara penelitian ini dengan penelitian sebelumnya yaitu terletak pada konteks yang digunakan. Pada penelitian Heriyadi \& Prahmana (2020: 402) konteks yang digunakan yaitu konteks lampion sedangkan pada penelitian ini peneliti menggunakan konteks lilin. Selain itu, berdasarkan hasil penelitian Efuansyah \& Wahyuni (2018: 39), penggunaan bahan ajar dengan pendekatan PMRI dapat memudahkan peserta didik dalam menemukan konsep matematika yang termuat pada setiap masalah yang disajikan dalam bahan ajar yang dikembangkan. Hal yang sama juga terdapat dalam penelitian Lestari \& Surya (2017: 98) yang mengatakan bahwa penggunaan pendekatan PMRI dalam pembelajaran matematika dapat memudahkan peserta didik dalam memahami konsep matematika yang sedang dipelajari.

Berdasarkan uraian tersebut, perlu dikembangkan suatu bahan ajar yang dapat membuat peserta didik berperan aktif dalam pembelajaran dan membantu peserta didik memahami materi bangun ruang tabung dengan lebih mudah. Untuk itu, peneliti mengembangkan LKPD berbasis pendekatan PMRI yang valid dan praktis dengan menggunakan lilin sebagai konteks pada materi tabung.

\section{METODE}

Penelitian ini merupakan penelitian dan pengembangan (Research and Development) yang bertujuan untuk menghasilkan LKPD berbasis pendekatan Pendidikan Matematika Realistik Indonesia (PMRI) pada materi tabung yang valid dan praktis. Subjek penelitian ini yaitu siswa kelas IX.1 SMP Negeri 40 Palembang. Prosedur penelitian pengembangan yang dilakukan dalam penelitian ini ada 2 tahap, yaitu tahap preliminary dan tahap prototyping. Pada tahap preliminary, peneliti melakukan identifikasi kurikulum dan 
identifikasi peserta didik. Sedangkan pada tahap prototyping, peneliti menggunakan formative evaluation alur Tessmer yang terdiri dari beberapa tahap yaitu self evaluation, expert review, one-to-one, small group, dan field test. Tahapan formative evaluation alur Tessmer (1993: 30) dapat dilihat pada Gambar 1.

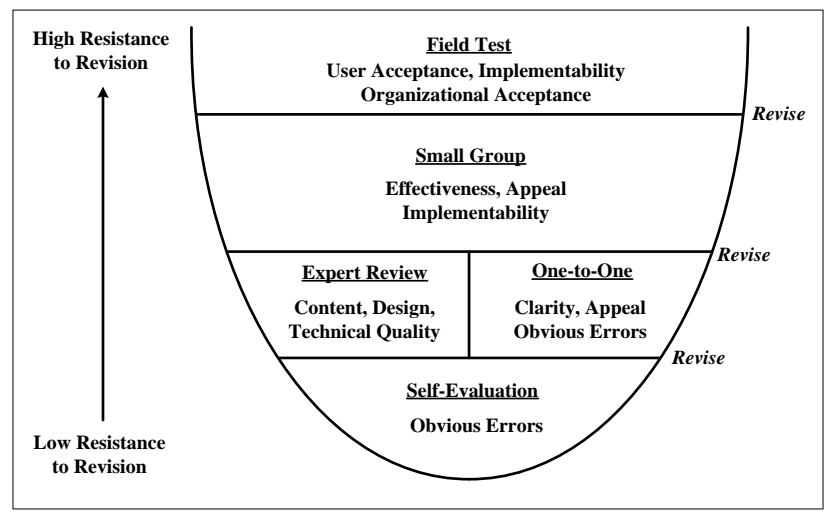

Gambar 1. Tahapan Formative Evaluation

Teknik pengumpulan data yang digunakan dalam penelitian ini yaitu dokumentasi, walkthrough, wawancara, dan angket. Dokumentasi digunakan untuk mengevaluasi LKPD berbasis PMRI yang dikembangkan. Walkthrough digunakan pada tahap expert review untuk memperoleh komentar dan saran dari validator sebagai bahan untuk merevisi LKPD dan mengetahui kevalidan LKPD. Wawancara dengan peserta didik dilakukan pada tahap one-to-one, small group, dan field test untuk memperoleh pendapat dan saran peserta didik mengenai LKPD yang sedang dikembangkan. Wawancara pada tahap one-to-one dilakukan secara face-to-face sedangkan pada tahap small group dan field test dilakukan secara daring melalui whatsapp video call. Angket respon peserta didik digunakan pada tahap one-to-one, small group, dan field test untuk mengukur kepraktisan LKPD yang dikembangkan.

Data dokumentasi, walkthrough, dan wawancara dianalisis secara deskriptif kualitatif. Sedangkan data angket dianalisis dengan langkah-langkah berikut:

a. Mengubah data kualitatif menjadi data kuantitatif dengan pedoman penskoran sebagai berikut:

Tabel 1. Skor Pernyataan Positif dan Pernyataan Negatif

\begin{tabular}{lcccc}
\hline \multicolumn{1}{c}{ Penilaian } & $\begin{array}{c}\text { Sangat Setuju } \\
\text { (SS) }\end{array}$ & Setuju (S) & $\begin{array}{c}\text { Tidak Setuju } \\
\text { (TS) }\end{array}$ & $\begin{array}{c}\text { Sangat Tidak } \\
\text { Setuju (STS) }\end{array}$ \\
\hline Pernyataan Positif & 4 & 3 & 2 & 1 \\
Pernyataan Negatif & 1 & 2 & 3 & 4 \\
\hline
\end{tabular}

Sumber: Modifikasi dari Widoyoko (2009: 236)

b. Menghitung rata-rata skor dengan rumus sebagai berikut:

$$
\bar{x}=\frac{\sum_{i=1}^{n} x_{i}}{n}
$$

dengan:

$\bar{x} \quad$ : rata-rata skor

$n \quad$ : banyak butir pernyataan

$x_{i} \quad$ : skor pada butir pernyataan ke-i

c. Mengkonversi rata-rata skor menjadi nilai kualitatif sesuai dengan aspek penilaian seperti pada Tabel 2. 
Tabel 2. Kriteria Hasil Produk Pengembangan

\begin{tabular}{cc}
\hline Kategori Skor & Kategori Respon \\
\hline $3,25 \leq \bar{x}<4,00$ & Sangat Praktis \\
$2,50 \leq \bar{x}<3,25$ & Praktis \\
$1,75 \leq \bar{x}<2,50$ & Kurang Praktis \\
$0,00 \leq \bar{x}<1,75$ & Sangat Kurang Praktis \\
\hline
\end{tabular}

Sumber: Modifikasi dari Widoyoko, 2014: 144

\section{HASIL}

Pada tahap preliminary, peneliti melakukan identifikasi kurikulum dan identifikasi peserta didik. Dari hasil wawancara dengan salah satu guru matematika diperoleh informasi bahwa kurikulum yang digunakan di SMP Negeri 40 Palembang adalah Kurikulum 2013. Subjek penelitian ini yaitu peserta didik kelas IX.1 yang terdiri dari 30 orang peserta didik dengan kemampuan akademik tinggi sampai dengan kemampuan akademik rendah. Selain melakukan identifikasi kurikulum dan identifikasi peserta didik, peneliti juga mendesain LKPD yang meliputi kegiatan peserta didik, latihan soal beserta kolom jawabannya yang sesuai dengan prinsip dan karakteristik PMRI. Desain LKPD atau draft prototype awal yang telah dibuat kemudian dievaluasi pada tahap prototyping menggunakan formative evaluation alur Tessmer.

Pada tahap self evaluation, peneliti mengevaluasi sendiri draft prototype awal yang telah dibuat. Aspek yang dievaluasi pada tahap ini yaitu kesalahan-kesalahan yang jelas, seperti menambahkan pengertian lilin pada kegiatan 1 agar peserta didik mengetahui sedikit informasi tentang lilin, menambahkan keterangan alat dan bahan yang dibutuhkan pada kegiatan belajar, dan membuat tujuan pembelajaran di setiap kegiatan belajar agar peserta didik mengetahui apa yang akan dicapai dalam pembelajaran. Hasil revisi pada tahap self evaluation dinamakan prototype 1 yang kemudian diujicobakan pada tahap expert review dan one-toone.

Pada tahap expert review, prototype 1 divalidasi oleh 3 orang validator yang terdiri dari 2 dosen matematika dan 1 guru matematika. Validasi ini bertujuan untuk mengetahui kevalidan atau ketepatan LKPD yang meliputi aspek konten (isi), konstruk, dan bahasa. Validasi dilakukan dengan cara meminta validator untuk memberikan komentar dan saran mengenai LKPD yang dikembangkan. Komentar dan saran dari validator ditulis pada lembar walkthrough yang telah disediakan sebagai bahan untuk merevisi LKPD. Berikut ini komentar dan saran dari validator mengenai LKPD berbasis PMRI prototype 1.

Tabel 3. Komentar dan Saran dari Validator

\begin{tabular}{|c|c|}
\hline Validator & Komentar dan Saran \\
\hline $\begin{array}{l}\text { Dr. Win Afgani, } \\
\text { S.Si., M.Pd. }\end{array}$ & $\begin{array}{l}\text { - Perbaiki beberapa kalimat pada LKPD yang kurang tepat } \\
\text { - Tambahkan } 2 \text { soal pada luas permukaan tabung dan volume } \\
\text { tabung } \\
\text { - Tambahkan narasi dalam soal yang sesuai dengan konteks dan } \\
\text { harus realistik } \\
\text { - Tambahkan gambar lilin pada bagian volume tabung }\end{array}$ \\
\hline $\begin{array}{l}\text { Veronika Fitri } \\
\text { Rianasari, M.Sc. }\end{array}$ & $\begin{array}{l}\text { - Harus lebih teliti dalam penyusunan kalimat } \\
\text { - Gambar pada LKPD sudah baik. Namun, hal yang harus } \\
\text { diperhatikan adalah penggunaan konteks }\end{array}$ \\
\hline
\end{tabular}




\begin{tabular}{ll}
\hline Validator & \multicolumn{1}{c}{ Komentar dan Saran } \\
\hline & Kelima karakteristik PMRI sudah nampak diupayakan oleh \\
& penulis \\
& Beberapa kalimat pada LKPD harus direvisi \\
\hline Fuji Lestari, S. Pd. & - Sudah sesuai dengan indikator dan kompetensi dasar. \\
& Tambahkan sedikit materi mengenai jaring-jaring tabung \\
& - Semua karakteristik PMRI telah tercakup dalam LKPD dengan \\
& cukup baik \\
& Gunakan bahasa yang mudah dipahami siswa \\
& Terdapat beberapa kalimat yang kurang tepat untuk \\
& mengarahkan siswa pada tujuan yang akan dicapai
\end{tabular}

Berdasarkan hasil validasi dari 3 orang validator dapat disimpulkan bahwa LKPD berbasis PMRI yang sedang dikembangkan termasuk dalam kategori valid dengan revisi. Setelah LKPD direvisi sesuai komentar dan saran yang diberikan oleh validator maka hasil revisi LKPD tersebut dinyatakan valid oleh validator.

Selain divalidasi oleh validator, LKPD berbasis PMRI prototype 1 juga diujicobakan pada tahap oneto-one dengan 3 orang peserta didik kelas IX dengan kemampuan rendah, sedang, dan tinggi. Pada tahap ini, peserta didik diminta untuk mengerjakan kegiatan dan soal-soal yang ada pada LKPD, kemudian peserta didik diminta untuk mengisi angket respon peserta didik dan diwawancarai satu per satu mengenai pendapat mereka ketika menggunakan LKPD yang sedang dikembangkan. Tahap one-to-one bertujuan untuk melihat kepraktisan LKPD yang dikembangkan. Praktis yang dimaksud adalah LKPD tersebut jelas, mudah digunakan, dan mempunyai daya tarik bagi peserta didik.

Berdasarkan hasil pengisian angket respon peserta didik oleh 3 orang peserta didik pada tahap one-toone, didapat rata-rata skor sebesar 3,66 sehingga dapat disimpulkan bahwa LKPD berbasis PMRI pada uji coba one-to-one memenuhi kriteria kepraktisan karena skor termasuk dalam kategori sangat praktis. Berdasarkan hasil wawancara dengan peserta didik didapat beberapa komentar dan saran mereka ketika menggunakan LKPD. Berikut ini komentar dan saran peserta didik pada tahap one-to-one.

\section{Tabel 4. Komentar dan Saran Peserta Didik pada Tahap One-to-One}

\begin{tabular}{ll}
\hline No. & \multicolumn{1}{c}{ Komentar dan Saran } \\
\hline 1 & $\begin{array}{l}\text { Bahasa yang digunakan mudah dipahami namun masih ada beberapa } \\
\text { kata yang membuat bingung seperti kata "sketsakanlah" }\end{array}$ \\
2 & $\begin{array}{l}\text { Gambar pada soal nomor 1 kurang jelas sebaiknya diganti saja } \\
3\end{array}$ \\
$\begin{array}{l}\text { Desain cover-nya sudah menarik, tapi lebih baik ditambahkan animasi- } \\
\text { animasi dan angka-angka pada desain cover LKPD agar lebih menarik }\end{array}$ \\
4 & $\begin{array}{l}\text { Pada kegiatan 2 sebaiknya tambahkan gambar plastik pembungkus lilin } \\
\text { yang sudah dibuka }\end{array}$ \\
& Pada bagian volume tabung cukup sulit karena tidak ada gambar lilinnya \\
\hline
\end{tabular}

Komentar dan saran peserta didik pada tahap one-to-one serta komentar dan saran dari validator pada tahap expert review dijadikan sebagai masukan untuk merevisi LKPD. Adapun keputusan revisi yang diambil yaitu memperbaiki beberapa kalimat yang kurang tepat, menambahkan sedikit materi dan soal mengenai jaring-jaring tabung, menambahkan soal tentang tabung yang berkaitan dengan kehidupan seharihari, menambahkan narasi pada setiap soal yang sesuai dengan konteks, menambahkan gambar lilin pada bagian volume tabung, menambahkan gambar animasi pada cover LKPD. Hasil revisi pada tahap expert review dan one-to-one dinamakan prototype 2 yang kemudian diujicobakan pada tahap small group. 
Pada tahap small group, prototype 2 diujicobakan pada kelompok kecil yang terdiri dari 6 orang peserta didik dengan kemampuan tinggi, sedang, dan rendah. Tahap ini dilakukan secara daring melalui whatsapp video call group dikarenakan pandemi Covid-19. Sebelum memulai video call, peneliti mengirimkan LKPD, angket peserta didik, dan alat peraga berupa lilin kepada masing-masing peserta didik menggunakan jasa antar barang online. Tahap small group bertujuan untuk melihat kepraktisan LKPD yang meliputi aspek efektif, efisien, dapat digunakan, dan menarik. Setelah belajar dengan menggunakan LKPD secara daring, peserta didik diminta untuk mengisi angket dan diwawancarai melalui whatsapp video call group.

Berdasarkan hasil pengisian angket oleh 6 orang peserta didik, menunjukkan rata-rata skor respon peserta didik pada tahap small group yaitu sebesar 3,46. Sehingga dapat disimpulkan bahwa LKPD berbasis PMRI pada tahap small group memenuhi kriteria kepraktisan karena skor termasuk kategori sangat praktis. Berdasarkan hasil wawancara melalui whatsapp video call group, peserta didik tertarik menggunakan LKPD yang dikembangkan. Menurut peserta didik bahasa yang digunakan mudah dimengerti dan mudah dipahami. Berikut ini komentar dan saran peserta didik serta keputusan revisi yang diambil pada tahap small group.

Tabel 5. Komentar dan Saran Peserta Didik pada Tahap Small Group

\begin{tabular}{lll}
\hline No. & \multicolumn{1}{c}{ Komentar dan Saran } & \multicolumn{1}{c}{ Keputusan Revisi } \\
\hline 1 & Bahasanya bagus karena mudah dipahami, & Peneliti hanya mengubah satu \\
soal-soal pada kegiatan 3 dan kegiatan 4 & soal yaitu soal momor 3 pada \\
lumayan sulit & kegiatan 3 \\
2 & $\begin{array}{l}\text { Cukup bingung pada soal nomor 3 karena } \\
\text { pertanyaannya mencari luas kertas kado }\end{array}$ & $\begin{array}{l}\text { Peneliti mengubah informasi dan } \\
\text { pertanyaan pada soal nomor } 3\end{array}$ \\
& $\begin{array}{l}\text { yang membungkus sebuah kotak sedangkan } \\
\text { dengan menanyakan luas kertas }\end{array}$ \\
& $\begin{array}{l}\text { yang diketahui adalah ukuran kaleng roti } \\
\text { yang berbentuk tabung. sebaiknya diubah } \\
\text { menjadi luas bungkus kaleng saja }\end{array}$ & roti \\
\hline
\end{tabular}

Dari hasil wawancara peneliti dengan peserta didik serta kesulitan dan kekurangan yang terjadi selama proses pelaksanaan uji coba small group dijadikan sebagai masukan untuk merevisi LKPD. Hasil revisi pada tahap ini dinamakan prototype 3 yang kemudian diujicobakan pada tahap field test.

Pada tahap field test, LKPD berbasis PMRI yang telah direvisi pada tahap small group atau yang disebut prototype 3 diujicobakan pada subjek penelitian yaitu peserta didik kelas IX.1 SMP Negeri 40 Palembang. Tahap field test dilakukan untuk mengonfirmasi revisi LKPD yang dibuat pada tahap sebelumnya dan mengetahui tingkat kepraktisan produk serta menghasilkan saran revisi akhir. Sama seperti small group, tahap field test juga dilakukan secara daring melalui whatsapp chat group dan whatsapp video call group. Sebelum memulai pembelajaran, peneliti mengirimkan alat peraga berupa lilin kepada masingmasing perwakilan kelompok menggunakan jasa antar barang online. Kemudian peneliti mengirimkan LKPD dalam format PDF melalui whatsapp chat group.

Peserta didik diminta untuk berdiskusi terlebih dahulu membahas LKPD melalui whatsapp chat group secara berkelompok, kemudian peserta didik diminta untuk menjelaskan hasil diskusi mereka melalui whatsapp video call group secara berkelompok. Setelah itu, peneliti meminta peserta didik untuk menjelaskan atau mempresentasikan hasil kerja kelompoknya kepada kelompok lain melalui whatsapp chat group. Peneliti meminta perwakilan setiap kelompok untuk membagikan hasil diskusinya kemudian peserta didik dari kelompok lain memberikan tanggapan mengenai hasil kerja temannya. Berikut ini jawaban LKPD peserta didik yang sesuai dengan prinsip dan karakteristik PMRI. 


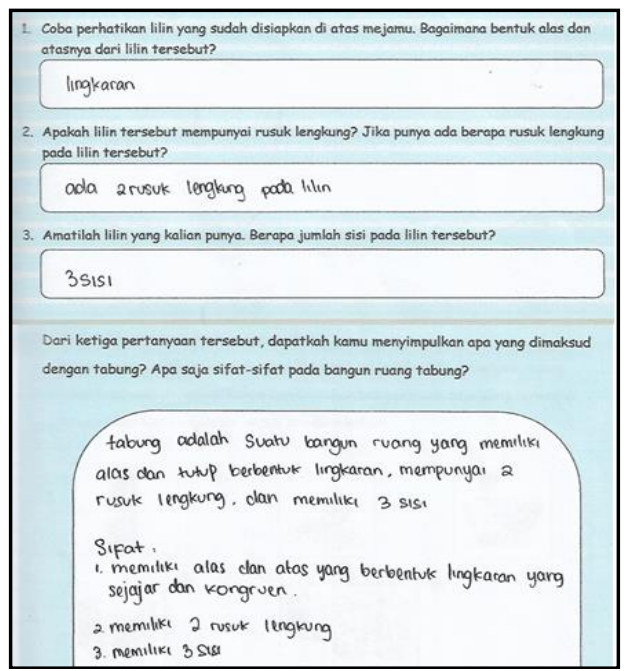

\section{Gambar 2. Jawaban Peserta Didik yang Memperlihatkan Prinsip PMRI Guided Reinvention Melalui Progressive Mathematizing}

Gambar 2. merupakan jawaban peserta didik yang memperlihatkan prinsip pertama dari PMRI yaitu guided reinvention (menemukan kembali) melalui progressive mathematizing (matematisasi progresif) dimana pembelajaran dimulai dari suatu masalah yang kontekstual atau realistik yang selanjutnya melalui aktivitas peserta didik diharapkan menemukan kembali sifat-sifat dan definisi tabung.

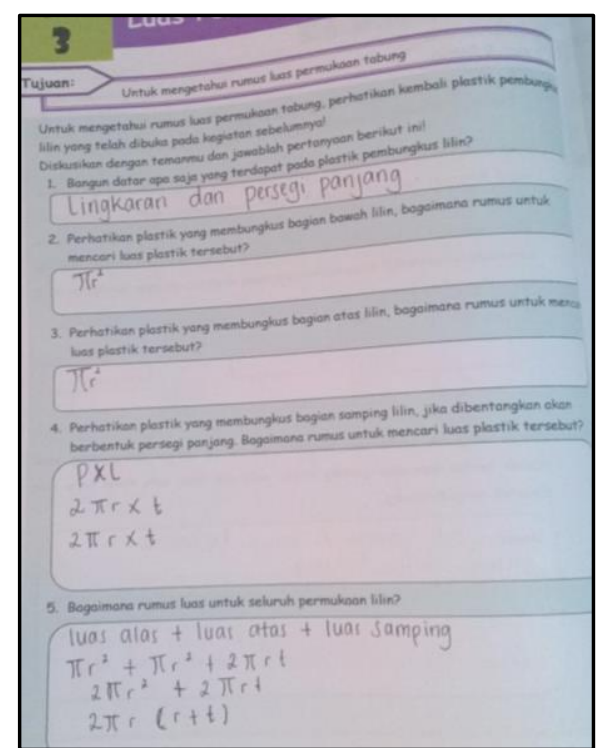

Gambar 3. Jawaban Peserta Didik yang Memperlihatkan Karakteristik PMRI

The Use of Models

Gambar 3. merupakan jawaban peserta didik yang memperlihatkan karakteristik kedua dari PMRI yaitu the use of models. Peserta didik menentukan rumus luas permukaan tabung dengan memperhatikan plastik pembungkus lilin yang telah dibuka.

Setelah belajar dengan menggunakan LKPD berbasis PMRI peserta didik diminta untuk mengisi angket melalui google form dan diwawancarai melalui whatsapp video call group. Berdasarkan hasil pengisian angket diperoleh rata-rata skor sebesar 3,01 sehingga dapat disimpulkan bahwa LKPD berbasisi PMRI pada uji coba field test memenuhi kriteria kepraktisan karena skor termasuk kategori respon praktis. 
Berdasarkan hasil wawancara dengan peserta didik, LKPD berbasis PMRI ini dapat membantu mereka untuk belajar materi tabung. Selain itu, peserta didik merasa senang dan tertarik menggunakan LKPD ini. Bahasa yang digunakan mudah dimengerti dan mudah dipahami. Namun, menurut peserta didik LKPD ini lebih mudah untuk dikerjakan di sekolah atau secara langsung karena mereka dapat berdiskusi secara langsung untuk mengerjakan langkah-langkah kegiatan yang terdapat dalam LKPD. Berikut ini dialog antara peneliti dengan peserta didik,
Peneliti
: Menurut kamu apakah LKPD ini mudah digunakan?
Peserta didik $\mathrm{ZO}$
: Mudah digunakan. Kata-katanya juga mudah dipahami.
Peserta didik $W$
: Mudah, Bu. Tapi soal-soalnya lumayan sulit.
Peserta didik $\mathrm{ZO}$
: Iya, Bu. Soal-soalnya juga menarik dan lumayan HOTS.
Peneliti
: Dimana kamu bisa menggunakan LKPD ini, di rumah atau di sekolah?
Peserta didik $S$
: Di sekolah, Bu. Karena bisa diskusi langsung sama teman-teman.

Setelah mengonfirmasi dari hasil revisi LKPD sebelumnya dan tidak terdapat saran untuk revisi selanjutnya, serta berdasarkan skor angket yang termasuk dalam kategori praktis, maka LKPD berbasis PMRI yang dikembangkan bersifat praktis dan dapat digunakan dalam pembelajaran.

\section{PEMBAHASAN}

Penelitian ini bertujuan untuk menghasilkan LKPD berbasis PMRI pada materi tabung yang valid dan praktis. LKPD yang dikembangkan merupakan adopsi dari LKPD yang sudah ada sebelumnya. Perbedaan LKPD yang dikembangkan dengan LKPD sebelumnya terletak pada desain LKPD, kegiatan peserta didik, dan konteks yang digunakan. Pada penelitian sebelumnya yang dilakukan oleh Heriyadi \& Prahmana (2020: 409) telah menghasilkan LKPD menggunakan pendekatan PMRI pada materi kubus dan balok kelas VIII SMP yang valid, praktis, dan memiliki efek potensial. Adapun konteks yang digunakan dalam penelitian Heriyanto \& Prahmana (2020: 402) yaitu menggunakan konteks lampion yang berbentuk kubus. Sedangkan di dalam LKPD ini peneliti menggunakan lilin berbentuk tabung sebagai konteks bagi peserta didik mempelajari materi bangun ruang tabung.

Menurut Akker (2006: 10) suatu media pembelajaran dikatakan berkualitas jika memenuhi kriteria valid dan praktis. Tingkat kevalidan LKPD yang sedang dikembangkan sangat penting terkait dengan materi yang tercantum dalam LKPD. Dalam pengembangan LKPD berbasis PMRI yang dilakukan peneliti, LKPD termasuk dalam kategori valid apabila memenuhi aspek kevalidan yaitu konten, konstruk, dan bahasa. Hal yang sama juga diungkapkan oleh Septy, Hartono, \& Putri (2015: 18), bahwa suatu bahan ajar dikatakan valid jika memenuhi karakteristik kevalidan dari segi konten, konstruk, dan bahasa.

Kevalidan LKPD pada formative evaluation alur Tessmer (1993: 30) dapat dilihat pada tahap expert review. Berdasarkan hasil validasi LKPD dari tiga validator yang telah dipaparkan sebelumnya dapat disimpulkan bahwa LKPD berbasis pendekatan PMRI yang sedang dikembangkan memenuhi karakteristik kevalidan dan termasuk dalam kategori valid dengan revisi. Setelah LKPD direvisi sesuai komentar dan saran dari validator maka hasil revisi LKPD tersebut dinyatakan valid oleh validator. Hal ini sejalan dengan yang dikatakan Putra (2013: 170) bahwa suatu bahan ajar dikatakan valid apabila telah direvisi sesuai dengan komentar dan saran dari validator.

Adapun komentar dan saran dari validator pada tahap expert review yaitu peneliti sebaiknya menambahkan narasi dalam soal yang sesuai dengan konteks dan harus realistik. Pada prototype 1 peneliti menampilkan soal yang menanyakan luas permukaan tangki dengan ukuran diameter alas $14 \mathrm{~cm}$ dan tinggi $28 \mathrm{~cm}$. Berikut ini soal latihan pada protoype 1 sebelum direvisi. 
1. Sebuah tangki minyak berbentuk tabung tertutup mempunyai ukuran diameter alas 14 $\mathrm{cm}$ dan tinggi $28 \mathrm{~cm}$ Lues seluruh permukoan tangki tersebut adalah

\section{Gambar 4. Tampilan LKPD Sebelum direvisi}

Menurut validator kedua, soal tersebut tidak realistik karena ukuran-ukuran yang diberikan bukan ukuran untuk sebuah tangki. Sedangkan menurut validator pertama, peneliti sebaiknya menambahkan narasi dalam soal yang sesuai dengan konteks dan harus realistik. Hal ini sejalan dengan Suherman (2015: 84) yang mengatakan bahwa soal-soal yang digunakan dalam PMRI merupakan soal-soal yang memiliki konteks sebagai titik awal bagi peserta didik dalam mengembangkan pengertian matematika. Oleh karena itu, peneliti memperbaiki soal yang terdapat dalam LKPD sesuai dengan saran dari validator. Berikut ini tampilan soal yang telah direvisi.

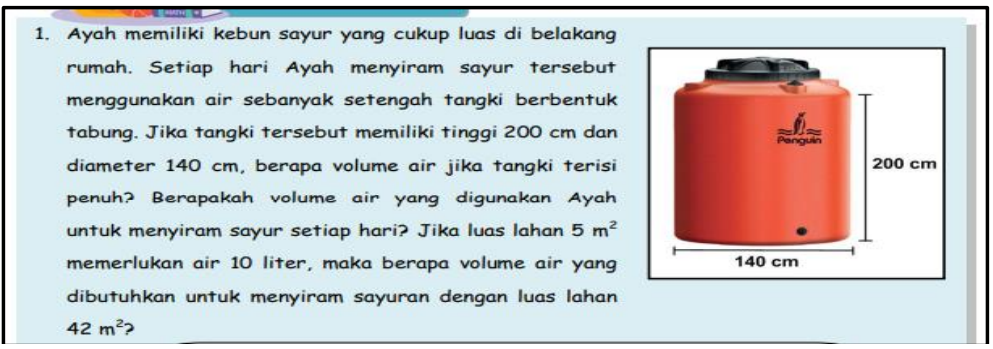

Gambar 5. Tampilan LKPD Sesudah direvisi

Selain memperbaiki soal-soal dalam LKPD, peneliti juga menambahkan sedikit materi tentang jaringjaring tabung sesuai saran dari validator ketiga. Berikut ini tampilan LKPD yang telah ditambahkan materi jaring-jaring tabung.

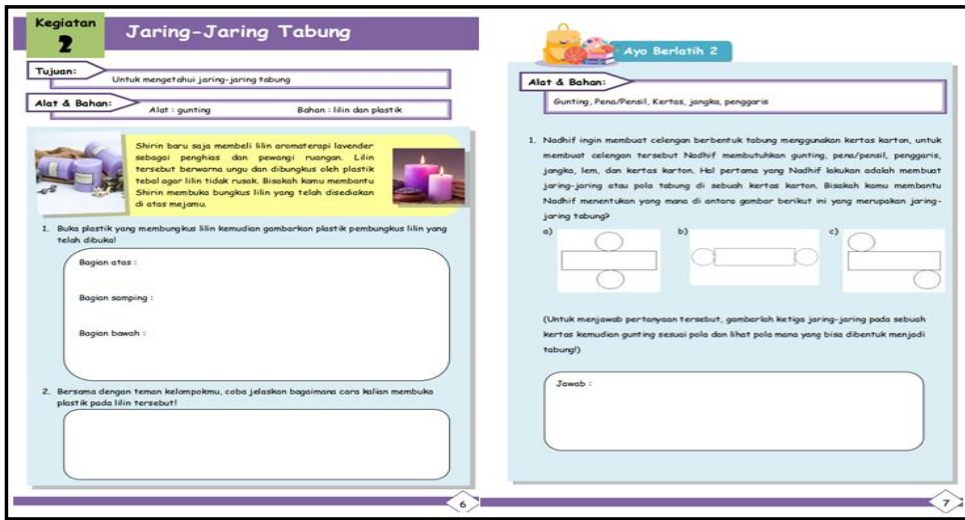

\section{Gambar 6. Tampilan LKPD yang telah ditambahkan Materi Jaring-Jaring Tabung}

Menurut salah satu validator, kelima karakteristi PMRI sudah terlihat pada LKPD yaitu penggunaan konteks (the use of context), penggunaan model (the use of models), kontribusi siswa (students contribution), interaktivitas (interactivity), dan keterkaitan (intertwining) (Treffers, 1987). Namun, hal yang perlu diperhatikan adalah pemilihan konteks yang digunakan sebagai titik awal pembelajaran matematika (Wijaya, 2012: 21). Pada prototype 1 terdapat kegiatan dengan menggunakan lilin sebagai media yang akan dipotong oleh peserta didik. Validator menyarankan untuk mempertimbangkan konteks tersebut, mengingat permukaan lilin yang licin dan membutuhkan waktu yang cukup banyak dapat menjadi kendala yang akan dihadapi di kelas. Oleh karena itu, peneliti mengubah kegiatan tersebut dengan kegiatan menyusun bagianbagian lilin yang berbentuk tabung menjadi balok. Berikut ini hasil revisi LKPD prototype 1. 


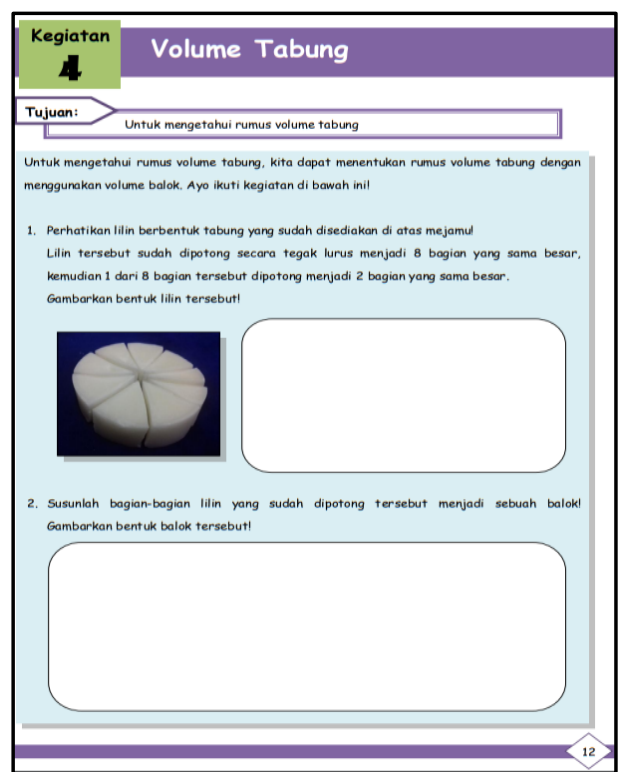

Gambar 7. Tampilan LKPD Prototype 1 Sesudah Direvisi

Berdasarkan hasil revisi, LKPD berbasis pendekatan PMRI pada materi tabung telah memenuhi karakteristik valid dilihat dari segi konten, konstruk, dan bahasa. Hal yang sama juga terdapat dalam penelitian yang dilakukan Trisnawati, Hartatiana, \& Wardani (2020: 30) bahwa LKPD dengan pendekatan PMRI yang dikembangkan telah sesuai dengan indikator kevalidan sehingga dinyatakan valid ditinjau dari aspek konten, konstruk dan bahasa. Karakteristik valid yang dilihat dari segi konten antara lain kesesuaian materi dengan Kompetensi Dasar, kebenaran dan ketepatan materi, kesesuaian dan kejelasan gambar, serta keurutan penyajian materi. Karakteristik valid yang dilihat dari segi konstruk yaitu memenuhi karakteristik PMRI dan memenuhi karakteristik LKPD. Sedangkan karakteristik valid yang dilihat dari segi bahasa yaitu ketepatan struktur kalimat sesuai dengan Pedoman Umum Ejaan Bahasa Indonesia (PUEBI) dan mudah dipahami, serta konsistensi penggunaan istilah dan penggunaan kalimat yang tepat.

Sedangkan untuk kepraktisan LKPD pada formative evaluation alur Tessmer (1993: 30) dapat dilihat pada tahap one-to-one, small group, dan field test. Tingkat kepraktisan LKPD diperoleh dari skor angket yang telah diisi oleh peserta didik setelah uji coba pada setiap tahap. Berdasarkan hasil angket respon peserta didik pada tahap one-to-one dan small group, LKPD yang dikembangkan termasuk dalam kategori sangat praktis. Sedangkan pada tahap field test, LKPD yang dikembangkan termasuk dalam kategori praktis.

Aspek kepraktisan yang dilihat pada setiap tahapnya berbeda-beda. Menurut Tessmer (1993: 30) pada tahap one-to-one aspek kepraktisan LKPD yang dilihat yaitu kejelasan, kemudahan penggunaan, dan daya tarik. Aspek kepraktisan LKPD pada tahap small group yaitu efektif, efisien, dapat digunakan, dan menarik. Sedangkan pada tahap field test aspek kepraktisan LKPD yang dilihat yaitu mudah digunakan. Pada tahap field test peserta didik juga memberikan komentar mereka terhadap LKPD melalui google form, dimana terlihat peserta didik senang dan tertarik belajar menggunakan LKPD berbasis pendekatan PMRI.

Adapun komentar dan saran peserta didik terhadap LKPD berbasis PMRI selama uji coba produk yaitu peneliti sebaiknya memperjelas resolusi gambar yang terdapat dalam LKPD. Pada prototype 1 peneliti menampilkan soal yang menanyakan gambar mana saja yang berbentuk tabung. Dalam soal tersebut, terdapat 2 gambar yang merupakan bangun ruang tabung. Namun, gambar tersebut kurang jelas karena resolusi gambar yang kurang bagus sehingga pada saat uji coba one-to-one peserta didik menanyakan kepada peneliti apakah gambar tersebut merupakan gambar kaleng yang berbentuk tabung. Berikut dialog yang terjadi saat peserta didik bingung untuk menentukan gambar mana yang termasuk bangun ruang tabung, 

Peneliti
: Coba tentukan gambar mana yang berbentuk tabung?
Peserta didik BDIN
: Gambar nomor 5, Bu.
Peneliti
: Kenapa gambar nomor 5?
Peserta didik BDIN
: Karena memiliki 3 sisi, kemudian sisi alas dan atasnya berbentuk lingkaran.
Peneliti
Peserta didik BDIN
: Iya, benar. Ada lagi gak gambar yang berbentuk tabung?
Peneliti
: Gambar nomor 1 tabung bukan Bu?
Peserta didikBDIN
: Menurut kamu itu gambar apa?
Peneliti

\section{Keliatan.}
Peserta didikBDIN
: Benar itu gambar kaleng. Apakah kaleng termasuk bangun ruang tabung? : Iya, Bu. Termasuk tabung.

Berikut ini tampilan prototype 1 dan hasil revisinya.

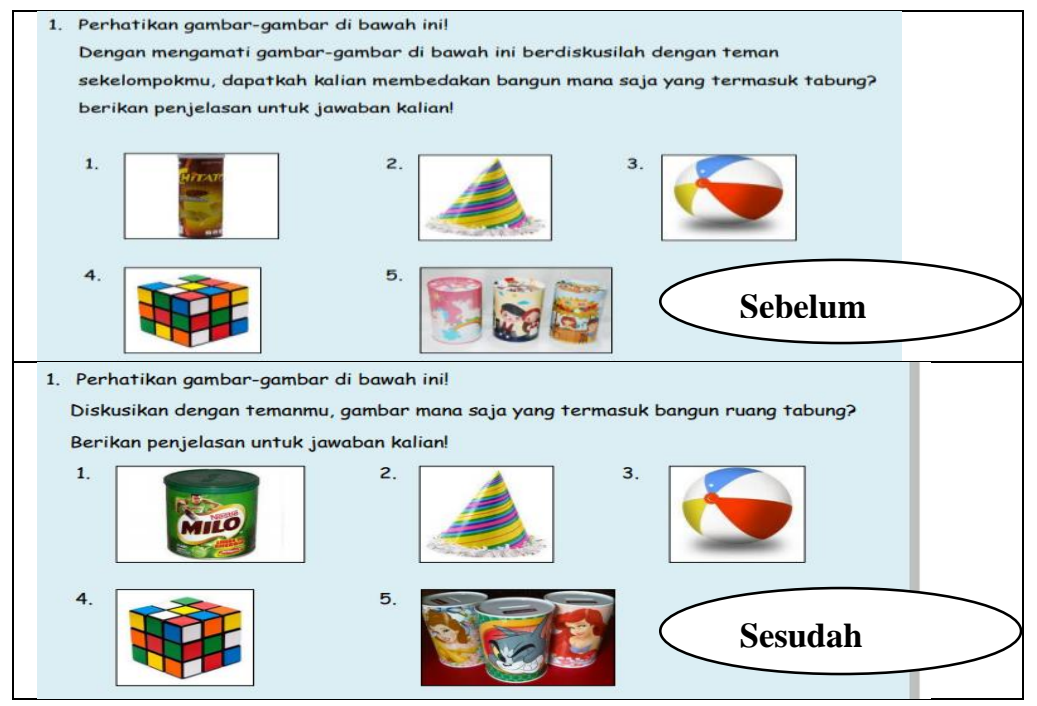

\section{Gambar 8. Tampilan LKPD Prototype 1 Sebelum dan Sesudah Direvisi}

Hasil revisi prototype 1 atau yang dinamakan prototype 2 kemudian diujicobakan pada tahap selanjutnya yaitu tahap small group. Pada tahap small group, menurut peserta didik gambar yang ditampilkan dalam LKPD sudah jelas dan tidak membingungkan. Hal yang sama juga terjadi pada tahap field test, menurut peserta didik gambar yang terdapat dalam LKPD jelas dan membantu mereka dalam menjawab pertanyaan-pertanyaan yang ada dalam LKPD.

Selain itu, menurut peserta didik desain cover LKPD sebaiknya ditambahkan animasi-animasi dan angka-angka agar lebih menarik karena salah satu aspek kepraktisan dalam pengembangan ini adalah LKPD menarik bagi peserta didik. Hal ini sejalan dengan Septy, Hartono, \& Putri (2015: 24) yang mengatakan bahwa salah satu karakteristik bahan ajar yang praktis yaitu menarik untuk digunakan dalam proses pembelajaran. Berikut ini dialog antara peneliti dengan peserta didik pada tahap one-to-one;

Peneliti

: Menurut kamu desain cover LKPDnya menarik gak?

Peserta didik BDIN

Peneliti

Peserta didik TR
: Menarik Bu, tapi kalau boleh ditambah animasi yang unik seperti ada orang atau anak-anak yang lagi gambar tabung atau tabungnya ada mata dan mulut.

: Kalau menurut TR bagaimana?

: Iya menarik, sebaiknya ditambah angka-angka dan kotak namanya di letakkan di tengah saja, Bu. 
Peneliti

Peserta didik TR

Peneliti

Peserta didik ANP
: Jadi kotak namanya ditengah ya jangan dipinggir?

: Iya, Bu.

: Kalau menurut ANP?

: Sebaiknya ditambah gambar atau animasi lagi, Bu.

Beriku tampilan cover LKPD sebelum dan sesudah direvisi.

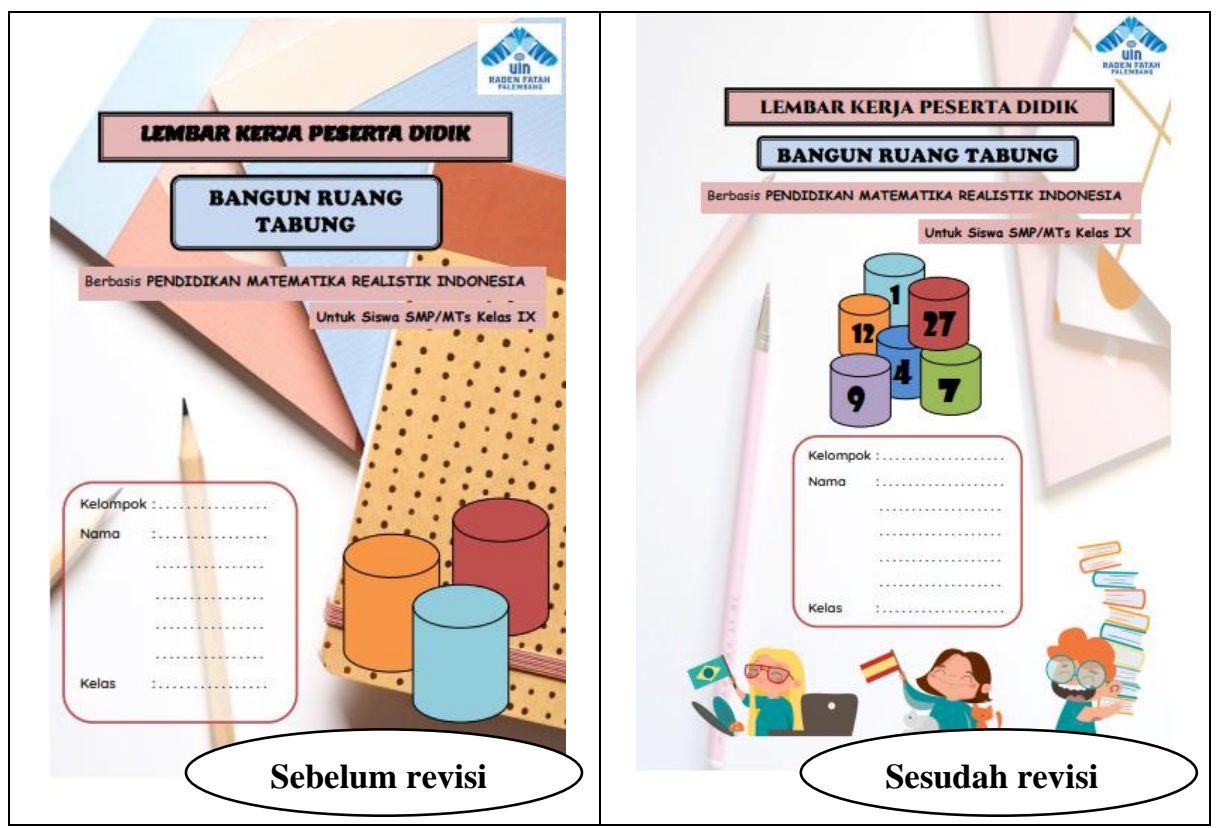

Gambar 9. Tampilan Cover LKPD Sebelum dan Sesudah Direvisi

Berdasarkan pembahasan di atas, LKPD berbasis PMRI pada materi tabung yang dikembangkan termasuk dalam kategori praktis. Komentar dan saran peserta didik pada setiap tahap dijadikan sebagai masukan untuk memperbaiki LKPD agar dapat memenuhi aspek kepraktisan seperti kejelasan, kemudahan penggunaan, dan menarik. Hal ini senada dengan penelitian yang dilakukan oleh Adha \& Refianti (2019: 8) dalam temuan penelitiannya mengatakan bahwa LKPD berbasis pendekatan PMRI dengan konteks Sumatera Selatan yang dikembangkan termasuk dalam kategori valid dan praktis. Hasil temuan serupa juga terdapat dalam penelitian Trisnawati, Hartatiana, \& Wardani (2020: 31) yang mengembangkan LKPD berbasis pendekatan PMRI pada materi penjumlahan bentuk aljabar yang valid dan praktis.

Adapun kelebihan dari LKPD berbasis pendekatan PMRI yang dikembangkan yaitu LKPD berbasis PMRI pada materi tabung ini membuat pelajaran menarik karena terdapat kegiatan-kegiatan yang menyenangkan seperti membuka plastik yang membungkus lilin dan menyusun puzzle dari bagian-bagian lilin. Selain itu, meskipun LKPD diujicobakan secara daring melalui whatsapp, LKPD yang dikembangkan tetap dapat membuat peserta didik aktif dan mandiri dalam pembelajaran karena di dalam LKPD terdapat kegiatan-kegiatan yang membantu peserta didik dalam menemukan konsep bangun ruang tabung.

Peneliti juga mengalami keterbatasan dalam penelitian secara daring dikarenakan learning from home (belajar dari rumah). Hal ini mempengaruhi kemudahan penggunaan dari LKPD yang telah dikembangkan, karena tidak semua subjek penelitian dapat menggunakan alat peraga secara langsung. Peneliti hanya mengirimkan alat peraga kepada perwakilan kelompok dikarenakan keterbatasan biaya. Oleh karena itu, untuk penelitian selanjutnya apabila ingin menggunakan alat peraga dalam pembelajaran daring hendaknya menggunakan alat peraga yang mudah dijumpai atau yang terdapat disekitar peserta didik agar setiap peserta didik tetap dapat mengikuti pembelajaran sesuai dengan tujuan pembelajaran yang akan dicapai. 


\section{SIMPULAN}

Penelitian ini telah menghasilkan LKPD berbasis pendekatan PMRI pada materi tabung yang valid dan praktis. Kevalidan LKPD ditunjukkan dari hasil penilaian validator pada tahap expert review yang menyatakan bahwa LKPD berbasis PMRI yang dikembangkan termasuk dalam kategori valid dengan revisi. setelah LKPD direvisi sesuai komentar dan saran dari validator maka hasil revisi LKPD tersebut dinyatakan valid oleh validator dari segi konten, konstruk, dan bahasa. Sedangkan kepraktisan LKPD dapat dilihat dari hasil angket respon peserta didik yang diisi setelah belajar menggunakan LKPD. Berdasarkan hasil angket respon peserta didik, LKPD yang dikembangkan termasuk dalam kategori praktis.

\section{DAFTAR RUJUKAN}

Adha, I., \& Refianti, R. (2019). Pengembangan Lembar Kerja Peserta Didik (LKPD) Menggunakan Pendekatan Matematika Realistik Indonesia Berbasis Konteks Sumatera Selatan. Jurnal Pendidikan Matematika (JUDIKA EDUCATION), 2(1), 1-10. https://doi.org/10.31539/judika.v2i1.729.

Akker, J.V.D. (2006). An Introduction to Education Design Research. The Netherlands: Netzodruk.

Ali, H., \& Rarini, M. (2014). Perencanaan dan Strategi Pembelajaran Matematika. Jakarta: PT. Raja Grafindo Persada.

Andari, T., \& Komsiatun, E. (2018). Pengembangan LKPD Berbasis Pendekatan Realistic Mathematics Education Untuk Meningkatkan Kemampuan Matematis Siswa. AKSIOMA: Jurnal Program Studi Pendidikan Matematika, 7(1), 155-160. https://doi.org/10.24127/ajpm.v7i1.1362.

Arifin, Yusmin, E., \& Hamdani. (2017). Analisis Kesulitan Belajar Siswa pada Materi Bangun Ruang Sisi Lengkung di SMP. Jurnal Pendidikan dan Pembelajaran Khatulistiwa, 6(4), 1-13.

Atika, N., \& MZ, Z. A. (2016). Pengembangan LKPD Berbasis Pendekatan RME Untuk Menumbuhkembangkan Kemampuan Berpikir Kritis Matematis Siswa. Suska Journal of Mathematics Education, 2(2), 103-110. https://doi.org/10.24014/sjme.v2i2.2126.

Azis. (2019). Analisis Kesulitan Siswa Dalam Menyelesaikan Soal Cerita Pada Pembelajaran Matematika Kelas VIII. Jurnal Akademik Pendidikan Matematika FKIP Unidayan, 5(1), 64-72.

Efuansyah, E., \& Wahyuni, R. (2018). Pengembangan Bahan Ajar Matematika Berbasis PMRI Pada Materi Kubus Dan Balok Kelas VIII. Jurnal Derivat: Jurnal Matematika dan Pendidikan Matematika, 5(2), 28-41. https://doi.org/10.31316/j.derivat.v5i2.139.

Haryonik, Y., \& Bhakti, Y. B. (2018). Pengembangan bahan ajar Lembar Kerja Peserta Didik dengan pendekatan matematika realistik. MaPan: Jurnal Matematika dan Pembelajaran,6(1), 40-55. https://doi.org/10.24252/mapan.2018v6n1a5.

Heriyadi, \& Prahmana, R. C. I. (2020). Pengembangan Lembar Kegiatan Siswa Menggunakan Pendekatan Pendidikan Matematika Realistik. AKSIOMA: Jurnal Program Studi Pendidikan Matematika, 9(2), 395-412. https://doi.org/10.24127/ajpm.v9i2.2782.

Isrok'atun, R. A. (2018). Model-Model Pembelajaran Matematika. Jakarta: PT. Bumi Aksara.

Jannah, U. R., \& Towafi. (2020). Realistic Mathematic Education pada Barisan dan Deret Aritmetika Berbasis Kehidupan Islami Pondok Pesantren. JKPM (Jurnal Kajian Pendidikan Matematika), 5(2), 165-174. http://dx.doi.org/10.30998/jkpm.v5i1.5163.

Khairani, M., \& Febrinal, D. (2016). Pengembangan Media Pembelajaran Dalam Bentuk Macromedia Flash Materi Tabung Untuk SMP Kelas IX. Jurnal Ipteks Terapan, 10(2), 95-102. https://doi.org/10.22216/jit.2016.v10i2.422. 
Lado, H., Muhsetyo, G., \& Sisworo. (2016). Penggunaan Media Bungkus Rokok Untuk Memahamkan Konsep Barisan Dan Deret Melalui Pendekatan RME. Jurnal Pembelajaran Matematika, 3(1), 1-7.

Lestari, L., \& Surya, E. (2017). The effectiveness of realistic mathematics education approach on ability of students' mathematical concept understanding. International Journal of Sciences: Basic and Applied Research (IJSBAR), 34(1), 91-100.

Nuraida, I. (2017). Analisis Kesalahan Penyelesaian Soal Bangun Ruang Sisi Lengkung Siswa Kelas IX SMP Negeri 5 Kota Tasikmalaya. Teorema: Teori dan Riset Matematika,1(2), 25-30. https://doi.org/10.25157/.v1i2.550.

Prastowo. (2014). Pengembangan Bahan Ajar Tematik Tinjauan Teoritis dan Praktis. Jakarta: Kencana Prenadamedia Group.

Putra, S. R. (2013). Desain Evaluasi Belajar Berbasis Kerja. Yogyakarta: DIVA Pers.

Septiyani, E., \& Apriyanto, M. T. (2019). Pengembangan Media Pembelajaran Matematika Berbasis Android untuk Tingkat SMP. JKPM (Jurnal Kajian Pendidikan Matematika), 5(1), 153-164. 64. http://dx.doi.org/10.30998/jkpm.v5i1.5230.

Septy, L., Hartono, Y., \& Putri, R. I. I. (2015). Pengembangan Media Pembelajaran Komik pada Materi Peluang di Kelas VIII. Jurnal Didaktik Matematika, 2(2), 16-26.

Suherman. (2015). Kreativitas Siswa dalam Memecahkan Masalah Matematika Materi Pola Bilangan dengan Pendekatan Matematika Realistik (PMR). Al-Jabar: Jurnal Pendidikan Matematika, 6(1), 8190. https://doi.org/10.24042/ajpm.v6i1.57.

Tessmer, M. (1993). Merencanakan dan Melakukan Evaluasi Formatif. London: Martin Tessmer.

Treffers, A. (1987). Three Dimensions. A model of Goal and Theory Description in Mathematics Instruction - The Wiskobas Project. Dordrecht: Reidel Publishing Company.

Trisnawati, S. E., Hartatiana, H., \& Wardani, A. K. (2020). Lembar Kerja Siswa Berbasis Pendekatan Pendidikan Matematika Realistik Indonesia untuk Materi Penjumlahan Bentuk Aljabar. Suska Journal of Mathematics Education, 6(1), 25-32.

Utarni, H., \& Mulyatna, F. (2020). Penerapan Pembelajaran Realistic Mathematics Education dengan Strategi Means Ends Analysis untuk Meningkatkan Kemampuan Berpikir Kritis. ARITHMETIC: Academic Journal of Math, 02(01), 15-34. https://doi.org/http://dx.doi.org/10.29240/ja.v2i1.1399

Widoyoko, E. P. (2014). Penilaian Hasil Pembelajaran di Sekolah. Yogyakarta: Pustaka Pelajar.

Widoyoko, E. P. (2009). Evaluasi Program Pembelajaran. Yogyakarta: Pustaka Pelajar.

Wijaya, A. (2012). Pendidikan matematika realistik: Suatu alternatif pendekatan pembelajaran matematika. Yogyakarta: Graha Ilmu. 
98 Mu'tashimah, Putri, \& Ramury

JKPM (Jurnal Kajian Pendidikan Matematika) Vol.6, No.1 (2020) 